\title{
Between Law and Legitimacy, between Local and Global: A New Case of Urban Collective Identity
}

\author{
Giovanni Olsson ${ }^{1}$, Monique Falcão ${ }^{2, *}$ \\ ${ }^{1}$ Communitarian Regional University (Unochapecó-SC, Brazil), Brazil \\ ${ }^{2}$ University Santa Úrsula, Rio de Janeiro, Brazil
}

Received September 1, 2019; Revised May 25, 2020; Accepted June 19, 2020

Copyright $\subseteq 2020$ by authors, all rights reserved. Authors agree that this article remains permanently open access under the terms of the Creative Commons Attribution License 4.0 International License

\begin{abstract}
Morro Azul is a poor community placed in a very rich area of Rio de Janeiro. Since 1950, when this community started to grow, it fights against the government and the real Market. While part of the State and Market try to remove or reduce the physic area of the community, it fights in a very independent way to stay, to grow and to legitimate itself as a local social and economic actor. From 90ths Morro Azul has improved its independency and legitimacy strategies. In parallel to the local government's aim to transform Rio de Janeiro in a global city, Morro Azul started to look for international recognition and investments, exploring its privileged physic location in a touristic area of Rio de Janeiro. Between (il)legality and (il)legitimacy, Morro Azul, government and formal Market fight for international investments. To reach this status, Morro Azul created international sports arenas, touristic services, cultural events and what they call "popular economy" or "solidarity economy". The singularity of this community gets deeper because of its peculiar collective identity. At a first look, it has no ethnical identity characteristics, neither a strong criminal remark. This work intends to describe this new collective identity as a foundation to keep the land. In addition to this, this work intends to identify how international investments shaped its identity and the fight for the territory in a city intending to be global.
\end{abstract}

Keywords Collective Identity, Actors, Global-Local Relations, Law and Legitimacy

\section{Introduction}

Morro Azul is a favela located in a noble area of Rio de Janeiro looking for national and international investments for development purposes since 1970. Like all other favelas, their creation and constitution are due to the lack of public policies for housing and social inclusion of ex-slaves in the post-abolition of slavery in the 20th century.

From the beginning 1950 s, this favela became closer to the Catholic Church and began to integrate urbanization programs promoted by the Church. In addition, it starts to build other networks and partnerships with various social actors.

The state remained absent, not promoting public policies. The threats of removal from the favela were neutralized by the reform of the barracos - shacks - and by basic sanitation policies promoted by the community itself in partnership with the Church. Since then, there have been no signs of State action against the favela. This is because the community has already strong and traditional political and social ties, either because the state didn't need to get in action.

In these two hypotheses, the results of community development strategies are consistent with the objectives of public urbanization policies. With the goal of becoming a global city, the city of Rio de Janeiro develops inclusive policies and attracts social and economic investments.

In a context of globalization in which the favela is located - including its privileged location in the South Zone of the city - the objective of this work is to demonstrate that its strategies are reconfigured according to development needs, which ends up determining also the reconfiguration of its collective identity.

As distinctive signs in relation to other favelas in the city, this work highlights, in the empirical field, the conception of community development, based on self-management and self-determination, without interference from external actors that offer them deterministic perspectives on how to proceed. While other favelas rely on criminal organizations, state actions, and non-governmental organizations (NGOs), Morro Azul bases its role on the lack of decisive influence of these actors and the non-determining cooperation of national and international partners. 
The theoretical-methodological contribution to thinking of such distinctive signs is two. First, the "power to", according to which power belongs to the group, holding it together with sufficient consensus during decision-making processes to develop projects for the common good. The other favelas would be under the "power over" trend, suffering decisive actions of state actors and of the third sector, being this the social representation that operates mainly like common sense.

Second, is the concept of identity for Dubar (2009). He criticizes what he calls essentialist conceptions of identity, because they treat belonging and difference as aprioristic ways of perception of each other. He defends what he calls nominalist conception which is founded on difference and belonging as a result of contingency instead of essence.

For Dubar, the advantage of the nominalist position is the possibility to think about the existence of personal identities, as people can accept of refuse identities offered by others. In a deeper way, people and groups can identify themselves in a different way from what others identify them.

To collective identities, Dubar contribution allows us to bring its historical processes which modify the configuration of identities forms defined by him as "modalities of identification", as a mix of commentary and socialist identifications. To him, there is no fundament to identify community forms such as identifications "for others" and societal forms with identifications "for themselves". In a communitarian dimension, these are "spatial" forms of social relations (relational axis), and in a society dimension, these are forms of temporality (biographical axis). These "relational" and "biographic" dimensions of identification combine to define what he calls "identity forms", which would be social forms of identifying individuals and groups in relation to others, and the duration of life (Dubar, 2009: 16-17).

The empirical object was constructed theoretically-methodologically based on the ethnomethodology of Garfinkel (1967). The French school of discourse analysis (Maingueneau, 1987 and Pêcheux, 1975) made it possible by extracting materiality from the speeches observed during interviews with Ubirajara Rodrigues, and from the diverse and fragmented documents that constitute the archive of the community.

This paper offers a diagnostic perspective on community identity as a new social movement with the active participation of beneficiaries in decision-making processes. This understanding can lead to the construction of a specific model of collective identity, through the exercise of participatory democracy, witch power derives from convergent (power to) rather than divergent (power over) actions.

The methodological procedures adopted in this research concern the deductive method, and the research has qualitative purpose. A bibliographical survey technique was used, once theoretical references were previously set.

\section{The Community of "Morro Azul" and Its Historical Role in Attracting Investments}

With the proclamation of the Republic, in 1889 , the city of Rio de Janeiro, until then seat of the imperial government, happened to be the capital of the federal government. Since then, public policies of urbanization, hygiene and beautification of the city were systematically implemented taking Paris Reform, from the period 1852 and 1870 by Haussmann, as the model (Abreu, 1987; Benchimol, 1992).

Thus, houses and cortiços - tenements - in the center of the city were demolished as part of sanitary policies and to allow the construction of wide avenues, buildings and modern economic centers. With this, residents evicted and with no money to buy or rent a new place to live started to build precarious housing in several hills of the city. They constitute themselves as irregular communities, without infrastructure and without government assistance. These are the favelas (Santos, 1993; Carril, 2006; Pechman and Fritsch, 1985; Vaz, 2002).

Morro Azul is one of these communities that grew up on the edge of the urbanization process. Struggling to insert itself into the current economic order, it had the participation of specific actors and with attraction and application of national and international investments for community development.

The main distinctive signs of the community in relation to other favelas are the existence of infrastructure, the low incidence of crime, the almost nonexistence of drug trafficking in the region, a solidarity economy network, symbiosis with trade and provision of services to the surrounding community and promotion of events with international visibility. The distinctive sign that characterizes the community is its protagonism, the self-management. Investments come from partners, and there is no external determinism regarding the modus operandi of the community.

Such distinctions reveal distance from the historical process of other favelas in the city of Rio de Janeiro. Among arguments for these differences, this works intends to highlight the late urbanization process of the Southern Zone and the self-management of the community with investment and technical guidance from national and international entities.

Unlike the center of the city and Rio de Janeiro's suburb, until the beginning of the 20th century, the southern zone was eminently rural, with few farms producing, with urban and rural occupation and development inferior to the center and the suburbs. Whether due to the topography that made it difficult to access and occupy the territory, or because of public options of various orders, the fact is that neighborhoods such as Botafogo, Flamengo and Copacabana had their urbanization processes intensified only from the beginning of the 20th century (Santos, 1993). 
A distinct sign of the process of urbanization in the south zone of Rio de Janeiro in relation to the center and other suburbs of Rio is the attraction of high society. The marketing was that in the South zone there would be a better quality of life. Privacy and contact with nature would be advantages over the harmful effects of other urban spaces, already occupied by industries, commerce, services and lower social classes (Abreu, 1987; Vaz, 2002).

For better understanding, the Morro Azul community will be presented from its historical process, with a description of its phases of installation, development and reforms made by the community in its territory. These phases had specific actors and collective actions for the development and inclusion of the community in the urbanization context of the city of Rio de Janeiro.

The main source of this article is the interviews granted by Ubirajara Rodrigues, during the year 2017. He is a resident of the community and was Residents' Association president for several years. Other interviews with other residents integrate this research, revealing details of the daily life and daily community experience during its development process. In addition, we have documentary sources of the historic collection of the Association of Residents.

Taking social reality as a starting point for scientific research, the theoretical-methodological foundation used is the critical theory of the Frankfurt School. For this school, social reality constitutes the level of immanence from which the theory must be questioned and constructed.

The objective of this critical research is to describe elements of social reality that allow to think the protagonism of the community in the construction of its own history, through a qualitative research, founded on the French school of discourse analysis (Maingueneau, 1987 and Pêcheux, 1975).

The analysis of sources external to the community will be done in subsequent stages of the research, in order to think to what extent the social reality distances itself from the programs of state public policies and other social agents of social inclusion.

Ubirajara identifies 4 phases of the community. These included the installation (from the 1920s to the 1940s), infrastructure (decades of the 1940s to the 1960s), urbanization (1960s to 1980s), and the development of public welfare policies (from the 1980s).

In the interviews, the interviewed highlight the efforts made for the construction of buildings and the implementation of services and the contribution of Priest Paul, due to the "help" he gave for "arranging" and "bringing" investments to the community.

\subsection{Community Morro Azul}

The Morro Azul community, located in the neighborhood of Flamengo, south zone of Rio de Janeiro, began to exist in the 1920s, when the first families-built shacks on a hill that borders two official buildings, the Guanabara Palace, government of the state, and the Isabel Palace, old imperial residence.

The entrance to the Morro Azul was made only by Rua Marques de Abrantes, behind a pub, called "Casa Azul". To reach the shacks and to bring groceries up the hill, residents had to use ropes because of their steep slope.

At the end of the 1940s, the second entrance was built after residents opened a street. This street would receive a subway station called Morro Azul in the 1980s. However, the rejection of the surrounding community regarding the association of the neighborhood with the favela made the name of the station changed to Flamengo.

In the 1950s the community had its development cycle intensified. The demands of the community became real with Priest Paul's help. He was a priest of the Catholic Church recently arrived from France to Rio de Janeiro. He was responsible for the local parish. The interaction between favela's residents and the parish of the region brought them closer to Church policies for "defavelization".

In 1954, the Morro Azul Committee was created to focus efforts to look for support from other community members and to organize decision-making. In addition, a group of Boy Scouts was created with the goal of "bringing awareness to the people," "teaching to take care of nature" and "taking care of health." Priest Paul attended the community's demands providing information and education.

In 1957, a fire in the favela destroyed 101 shacks, leaving these and other families homeless. Faced with the non-fulfillment of the "promise made by the Major" to guarantee housing for such families, its residents began to rebuild, on their own, not only their homes, but collective areas for living.

The relationship between Priest Paul and the community intensified, and the favela was included in the São Sebastião Crusade program. This program was led by Dom Helder Câmara, an influential Cardinal from Rio de Janeiro who, from the 1950s on, had the specific objective of constructing housing projects such as resettlement of favelas in Rio de Janeiro.

Among the principles of the Crusade ${ }^{1}$ was the non-physical displacement of the community and to give support for self-management and active community participation in infrastructure works in order to preserve bonds of solidarity created among its inhabitants.

\footnotetext{
1 "The São Sebastião Crusade is a private entity founded on September 29, 1955 by Archbishop Helder Câmara at the time Auxiliary Archbishop of Rio de Janeiro, with the purpose to collaborate in the human and Christian solution of the problem of the favelas of that city" forcing public power and private initiative "to engage in educational actions for humanization and Christianization in the community sense, starting from urbanization as a minimum condition of human experience and moral, intellectual, social and economic elevation. social promotion, Box A (1/8), folder 007 . Collection Maria Luiza and Edgar Amarantes, made available by the Memory Center of PUC-Rio.
} 
As a pilot project, two favelas in the south of Rio de Janeiro participated in the program: Praia do Pinto in Leblon and Morro Azul in Flamengo.

Among the distinctions between these two favelas considering acceptance and effects of the Crusade, is the fact that the Morro Azul community took the initiative to get closer to the Church. The Community also agreed to build a housing complex, taking part in the negotiations and contributing to labor and collective joint efforts. The community added to the civilizing proposal of the Crusade, the speech to accelerate the construction of housing to ensure ownership of the land and avoid removal of the favela, under the strong threat of local public power.

In Praia do Pinto, studies from a private University in Rio de Janeiro - PUC-Rio - point out that the initiative to build the São Sebastião neighborhood started initially from the Church. The residents of Praia do Pinto did not participate in the elaboration of the project, which was followed by a high rejection against the execution of the works. In spite of that, 10 buildings with 945 apartments, which now constitute the condominium Prédio de Pedra, were built in 10 years by the Church.

For the construction of the first building of the future Morro Azul condominium, an agreement was made between residents of the Morro Azul favela and the Crusade. Among the clauses, was the use of voluntary labor of the residents of the Morro Azul, which entailed a reduction of the values paid for the apartments.

In addition, Morro Azul went beyond the objective of building infrastructure and houses of the Crusade for having sought - and received - national and international investments for the economic development of the community for purposes of inclusion in the global economy. Other studies on Praia do Pinto, nowadays Selva de Pedra condominium or even São Sebastião neighborhood, did not reveal the same intensity and variety of economic activities and relations with the surrounding community.

In addition to the housing issue, sanitation works and services were performed with the aim to reduce child mortality that was around $80 \%$ between 1920 and 1950 , as part of the Crusade program and to attend demands of the residents.

The residents agreed with the sanitary proposals of "Dr. Luiz ", brought to the community by Priest Paul. Among the proposals was to finish animal husbandry, to open streets instead of alleys, and to create underground ditches as a sewage network, built on a multi-stakeholder basis by the community. Among the ills that were intended to eradicate were typhus and tuberculosis and the death of approximately 7 children per week.

Then, the youth group of the community was constituted at this time with the aim to develop the cultural part of the favela, with music, dance and sports events.

At the end of the 1970s, after the construction of the Morro Azul Building, the community started to replace the remaining shacks with brick houses. As the investment of the Catholic Church would be insufficient to meet the demand for construction of 350 houses, the headquarters of the Association of Residents and the Cultural Center, the Association of Residents obtained international investments of "agreements with the outside", being expressive the participation of the Interamerican Foundation.

The first work to be carried out was the headquarters of the Association of Residents, in "strategic place, just at the entrance of the community" with the purpose to be the "visit card" of the community, a "cultural center" and to receive "visitors and authorities". The identification band of the Association of Residents headquarters revealed the community's role and partnership with the Parish: "Here we are building our Cultural Center with the support of the Holy Trinity Parish" - AMBA.

Later, a health center was set up to provide medical and dental care for the residents. The partnership in the 1990s with the International Lions Club allowed the community to receive equipment by donation and regularly attend pediatric, gynecology, dentistry, general practice, and geriatrics.

In order to receive medicines and perform tests free of charge, the Association of Residents signed an agreement with the private company Equipe Guanabara and with the Municipal Health Center Manoel José Ferreira, implementing the "Solidary Medical Program", which operates until today as a free health plan existing to this day for community members.

In the field of education, also in the 1990s, the nursery Padre Aleixo was built in partnership with the SESI system (industrial social service), and also the construction of a community library. Both are still working with the aim to "not to let children go to drugs trafficking".

The Educafro Project (afro-education) was also created in the 1990s, starting as a preparatory course to universities admission "for blacks and needy people." Created by "Frei David da PUC", the project provides for $100 \%$ scholarships for community students in the universities Pontifícia Universidade Católica - PUC-RJ and Fundação Getúlio Vargas - FGV-RJ. In addition, it provides agreements with scholarship institutions at the master's and doctoral level. Some houses of the community were turned into student republics to give assistance and welcome to the students who would not be able to maintain themselves alone.

\section{Strategies of Inclusion in a Globalized Economy}

In the 1980s, when the subway station "Morro Azul" was built on the region, the community rejected the name because it was a "favela" and it was not "adequate" to the local society. After a long fight between inhabitants of the community and neighborhood, the name has been changed 
to Station "Flamengo", because this was the "correct name of the place" and of "the city". The construction of the metro reduced entrance roads to the community. Until today the community claims for the area used by Administration of the subway as an old area for plantation and cultural activities.

In 2000, the local government included the community on the Project Bairrinho, which aim to urbanize and bring infrastructure to the region. The project Bairrinho is a specific project, to favelas with less population, in the municipal program Favela-bairro. However, as Joao Calafate, an architect from the local government responsible by the project in every favela of the city, affirmed in an interview granted in October 2017, the community was the only favela in which the local government "had nothing to do". The reference, in truth, was in rapport to infrastructure for sanitary, sewer and construction of houses and collectives' areas of convenience.

What local government "really did" was to build a viaduct to enable the access of inhabitants to the highest point of favela, to build a new water reservoir of 65 thousand liters, to circulate weekly a cleaning truck, and to include the community in programs of reforestation.

The community started to look for sustainable economic activities founded on what members from Association of Residents called "solidarity economy". To Ubirajara Rodrigues, the "solidarity economy" is the "management of resources created for the community itself", with the aim to "get better" and "preserve wellness".

The place chosen by Association of Residents for the construction of Popular Market was the area close to the entrance for the community, at Station Flamengo. There was built parking, cleaning services for cars, 13 small stores, as restaurants, cleaning shops, small churches, pizza, coiffures, and taxis. As cultural activities, a music school and a football school were built for the community.

Besides those economic activities, Association of Residents started to look for, from the year 2000 on, at international investments and projection. The aim is to be "an organized and entrepreneur community" and start "to behave as a Creative Favela in a Creative City".

The 1990s at Rio de Janeiro are remarked by policies of embellishment and entrepreneurship. Rio de Janeiro lost its status of the main capital of the city because of the transfer of the headquarters to Brasília at 1950 and after the economic crisis in the 1980s. After that, the economy of the city lost traction because it was founded on services to the central government.

The main strategy to re-establish the economy of the city was the projection of the city as a global city. The city decided to invest in services, mainly communication, transport, free time, and culture. The aim was to bring international enterprises, mainly from the financial market and focused on services. With this, the global city got apart from the conception of megacity, founded only on industries and activities of intermediation and commerce.

The main feature Rio wants to invest to be considered a global city is the participation in international events, to get better the quality of life, attraction of headquarters of multinationals enterprises and universities, and communication and transports infrastructure.

Getting to know public policies of internationalization of the city of Rio de Janeiro, inhabitants and members of Association of Residents decided to attract investments for sports, culture, free time, and tourism for the region.

Recognizing the potentiality of placement of the community, in a rich and touristic area in the city, economic activities to be developed on the community started to be attractive for tourists.

Reuniting all demands of the tourism market and history itself of the community, investments were done for hostels, to rent houses and spaces and buildings of infrastructure for ecological tourism. For that, they looked for partnerships with Universities, public organisms, and international entities.

One of them was the construction of "Upper Arena", called "New Center of Training of New Union", opened at 2017 as headquarter of the Japanese enterprise "Shooto". This is one of the leaders of "MMA". The responsibility for the enterprise is André Pederneiras, trainer of José Aldo, Leonardo Santos and Vitor Shaolin, athletes for martial arts internationally recognized. José Aldo trains and takes parts at projects with social projection in the community.

The "Upper Arena" was built close to Popular Market. Originally it was built as a reaction to abandoned space by Subway stations Marques de Abrantes. The first function the community gave to the popular market was the organization of a school of graphic arts, between 1982 and 1985. The investment comes from Legião Brasileira de. Assistência - LBA, inaugurated by the wife of Republic President at that time, José Sarney.

From 2010 on, the community search again for the support from Interamerican Foundation for reforms, buildings and better works, considering proposals from Local Plan for the development of Morro Azul - PDLMA, whose needs are to be "holistic, interdisciplinary and transdisciplinary". Its origins come from "necessity to keep on a hard work which started since for sixty-five years" (PDLMA, 2016:4).

The main aim is to promote the "community progress, this alive organism stays dynamic serving their characteristics, giving value and preserving their traditions and histories" (PDLMA, 2016:4). PDLMA has as the beginning of development the arrival of Priest Paul at Brazil, because "at the beginning of Dec. 1950", making his visits and interventions in the favela, he started to draw possibilities to have local development at Morro Azul" (PDLMA, 2016:5)

\footnotetext{
${ }^{2}$ http://www.shooto.com.br/index.htm
} 
Besides the reform of popular market, reforms on the main street and restoration of built houses with support from Priest Paul, the PDLMA has as specific targets the following: the building of Cultural Centre José Rodrigues, the amplification of structure, rebuilding of the terrace and last floor with acoustic coating, and cyberspaces as a permanent model, aiming to promote technological inclusion and social events.

The Municipal Center of Integrated Social Assistance CEMASI is nowadays occupied with police service. The PDLMA proposes the installation of the headquarters of Carioca Agency for Local development - ACDL. The objective of the Agency is to develop community tourism, religious tourism, urban ecotourism, gastronomic tourism, with following activities: Morro Azul program with open doors, building of a spot in honor to Holy Lourdes, a saint for them, Holy Lourdes Woods, and Program Center School for gastronomy and hospitality.

The region is nowadays known for its touristic area, because of its natural beauty and cultural activities from Morro Azul.

Besides those projects, there is too the construction of a museum in an old-style shack, from 1950s, with furniture and other housing objects.

There is also the program "Sítio Urbano", a "creative production" for "agricultural and social products and services", with qualification courses, direct and solidarity commercialization, the creation of workshops, researches and partnerships with universities (PDLMA, 2016:11-12).

Those strategies and features reveal characteristics from new social movements (Gohn, 1997 and 2010). The objective of social groups, on contemporaneity, is to fight for social and economic inclusion to have public and private services offered by society and by State. The protagonist of new social movements is revealed by agreements and partnerships with national and international, public and private institutions, with the aim to develop economic activities able to give them visibility and legitimacy for civil society and State.

This community wishes to overcome these issues of illegality and illegitimacy through strategies redefining its collective identity as a distinctive sign. The specification of the identity of this community is the overcome of a dualist perspective of opposition which remarks the favela in rapport to State and civil society. The protagonist of Morro Azul shapes its identity as social actor looking for inclusion and development in an active perspective and non-dependent from State asking for specific public policies.

\section{4. "Power to" and "Power over" Relations and Social Movements Performance in Global-Local Aims}

A characteristic of new social movements (Gohn, 1997,
2010 ) is the fact that their strategies to fit in global level are to be more consensual with current social actors. They look for been recognized and look for access to fundamental rights and to the market instead of fighting against the established system, as classical social movements used to do (Gohn, 1997 and 2010).

The understanding of the protagonist of new social movements presupposes the recognition that, as international actors, they play diverse roles in the contemporary globalized society. In addition, the projection of social movements at both the local and global levels become possible through the articulation of global and local interests or, more simply, local ones.

However, unlike other traditional actors, such as the state and international intergovernmental organizations, the protagonist of these actors is remarked by the preponderant exercise of a characteristic form of power: "power to", as opposed to the classic definition of "power over". So, the focus of this study at this time is to recast these categories in the context of contemporary theories of power to sketch how the social movements identified here in the community of the Morro Azul exercise their differentiated power.

First of all, it must be remembered that power integrates the most elementary human relations and its study pervades the history of humanity itself, and for a long time has been "taken for granted", or understood as a self-explanatory concept. He finds roots, for example, in Aristotle's writings on human nature, when he defines man as a 'political animal' in order to explain the rising of state, and when he points out human's 'power of speech' (1996: 13). The high point of this pragmatic view of the phenomenon is certainly in Machiavelli, when he deals with the mechanisms for acquiring and maintaining power by the Prince, without, however, worrying about a concept which, as he points out, does not have to be "embellished" (1988: 03). This fact was not unnoticed in the contemporary studies. Some authors point out that political scientists of previous centuries were not concerned with aspects of power particularly interesting for social scientists of the twentieth century (Dahl, 1986: 38-9).

More than that, the debates about power are in the most diverse areas of the knowledge and under diverse cleavages. In addition to Political Science, the subject is directly interesting for Economics, Law, Psychology, Medicine, Management and, in one way or another, practically all sciences.

However, the attentive reading of the most diverse studies of power shows not only different approaches (normative, pragmatic, etc.), but singular cuts on several aspects. For example, there are studies on its symbolic dimension (Bourdieu, 1991), its centrality in the nation-state (Hobbes, 1957), its relational character (Weber, 1980), its relation to violence (Arendt, 1970), its fluidity (Parsons, 1967), and its social diffusion (Foucault, 1994). Those are just samples of the immense wealth (and 
difficulty) to study the subject.

As we can see, this study is dedicated to a very specific aspect: the direction of its exercise, although there are many other ways to systematize power studies around their categories, origins, natures, and other variables. In order to stress this difference, two groups of concepts are initially pointed out.

On the one hand, Weber's conception should be highlighted. It is evident that this author regarded power as an attribute of the nation-state in Hobbes tradition, which, in its constitution, assumed the monopoly of legitimate violence, expressed by its acts of the empire, such as taxation, police, and prison of criminals. He points out: 'Power is the probability, within a social relationship, of realizing one's own will even against resistance, regardless of the basis on which this probability rests' (1980: 28).

His in-depth study of the division of power in society extends to an important part of 'Economy and Society' (1980, Chapter VIII) and culminates in the dissociation of its three classic types of 'legitimate authority': 'rational-legal normative authority' (grounded on status), 'traditional authority' (based on wealthy), and 'charismatic authority' (rooted in rulership) (1980: 124). Power, in his understanding, would then be exercised in conflicts that relate to status, wealth and / or rulership. Within each category and between different categories, there would be conflicts in which one individual or group would wield power over another to make his will to prevail, regardless by physical force or another means. In a loose way, a look at Hobbes and Machiavelli's studies points out the same idea: power is a possibility or a concrete act of imposing the will of one subject to another.

On the other hand, we can remember Arendt's works, which take a great leap to illuminate dark areas of the theme. She says that power human means 'the ability not just to act but to act in concert. Power is never the property of an individual; it belongs to a group, and remains in existence only as long as the group keeps together' (1970: 44). It means that power is better expressed not by 'command-obedience' relations, but is rather consensual (1970: 40). Recurring Aristotle's conception of man as a political animal, she highlights productive, or constructive, the face of human action in society as an exercise of politics. Arendt's idea was not unnoticed by other scholars. Habermas, for example, assigned to her a 'communicative concept of power', and adds: 'Power, therefore, manifests itself (a) in orders that protect liberty, (b) in resistance against forces that threaten political liberty, and (c) in those revolutionary actions that found new institutions of liberty' (1986:77).

Parsons makes a similar approach in his well-known idea that power would be a 'generalized medium' functionally closed to money and to its role in economics (1967:300-1). Power, in this trend, is something like the blood that circulates in the social body.

Parsons highlights that power is a key concept in
Western society, but it is usually treated as a means of coercion, which does not portray its integral reality. He had already perceived a gap or deficiency in the understanding of the phenomenon, particularly 'the relation between the coercive and the consensual aspects' (1967: 298), which did not give due attention to acting by free will or consensus.

These two ways of understanding power are clearly different, but for a long time they were not identified and exploited in all their potential to understand the phenomenon.

However, the perception of this important difference between the two trends to understand the power is attributed to Piktin's pioneering study. As Goehler notes (2000: 42), the author introduces a "big divide" in understanding the subject, noting that there are two groups of theories that gravitate around different axes, and that make up two species of power: "power over" and "power to" (Pitkin, 1972).

One of them, which can be portrayed with the mentioned works of Weber and Hobbes, for example, fits the "power over" framework. The other can be exemplified in the cited works of Arendt and Parsons, and portrays the "power to".

This distinction was perceived by other contemporary authors once their characteristics became better remarked by their own terminology. Dyrberg, for example, refers to these two lines in the exercise of power as 'asymmetrical' and 'symmetrical' conceptions (1997: 02-3).

The asymmetric would correspond to conflicts of interest over assets or values, in which the relationship of subordination or control of one agent over the other (whether individual or collective) would be decisive for the outcome of the clash, which would consist of a zero-sum game, because one's gain would be directly proportional to the loss of the other. The symmetric, in the opposite sense, corresponds to a conflict in which the parties are not in a relation of subordination and the power then is a 'collective ability grounded on consensus', and thus 'everyone that takes part in this relation is able to win, because it is a positive result or pay-off game' (1997: 02). Power, in the last case, is positive and constructive or "productive", as Foucault has already pointed out (Foucault, 1994).

At the same direction, using other terminology to explicit the same phenomenon, Goehler points out that both conceptions ("intransitive" and "transitive" power) refer to different types of relationships involving the word power. In the same strand, and using other terminology to make explicit the same phenomenon ('intransitive' and 'transitive' power), he goes on to say that Weber focused on one, and, in contrast to this idea, 'Hannah Arendt conceives power as a relationship between persons who develop in the form of communication and joint action, and is not primarily directed towards people outside. '(2000: 43).

This contemporary theoretical contribution is extremely rich and, although it cannot be further elaborated in this article, it offers an extraordinary help to understand 
complex relations of power in the globalized contemporary society. Whether as 'power over or power to' (Pitkin), as 'asymmetrical' and 'symmetrical' power (Dyrberg), or 'intransitive' and 'transitive' power (Goehler), these categories constitute a tool of great importance to political theory.

In other words, and normatively, the 'power to' concept can be considered a normative idea, and as an intransitive power, 'constitutes a community as an effective unit in the form of a common space of action which is symbolically present' (Goehler, 2000: 48), because it concerns exactly to 'generation of collective capabilities' to political life (2000: 46) as noted by Arendt. Empirically, in contrast, the 'power over' concept is, in the Weberian claim, 'the probability, within a social relationship, of realizing one's own will even against resistance, regardless of the basis on which this probability rests' (1980: 28).

Political power, therefore, as an operational concept in this work, can be taken as the twofold ability to, on the one hand, subordinate B will according to A will (empirically, 'power over') and, on the other hand, allow A and B to 'act in concert' to obtain 'collective capabilities', regardless it is practical or discursive, expressed or symbolic (normatively, 'power to').

In the specific case studied, the Morro Azul community, considering this theoretical tool, it is evident that the type of power exercised by the community has a very different nature from that power exercised by the State.

On one hand, and as explained, favela claims for autonomy to promote improvements in infrastructure and provision of services arguing that the government is absent and doesn't recognize its original identity to develop in a global economy. This is what we could now call the wield of "power to". On the other hand, the state government claims to be the guardian of favela's infrastructure, arguing that it is in the public interest to include them in a modern global city, what is wielded of "power over".

The hypothesis to be investigated is that the whole community activity as a social movement is an authentic exercise of participatory democracy in which all people living in the community take their place in the debates about their future. The destination of resources and projects of sanitation, housing, street paving and development of its local economy, with the creation of a community market, for example, are internal deliberations of the community. The productive power builds new possibilities for the exercise of citizenship, in which the direct beneficiaries of these initiatives are also active participants in decision-making, and who consider their own limits and possibilities. There is no individual loss, but the full exercise of participatory democracy, legitimized by democratic procedure, whose center of power and decision is located territorially within the community itself (in its Association of Residents, especially), as a "power to" something new or better for everyone living there.

On the other hand, the State's "power over" emerges in a totally different direction. It is part of the state power center, several miles away, and is exercised by persons whose legitimacy results from the formal exercise of elective positions intermediated by representative democracy, and for this election concurred votes from several other regions of the city and other communities. In this regard, and considering the model of Brazilian representative democracy, in which there is no district vote, it is probable that the elected have a much greater affinity in terms of political projects and even life project with larger communities and very different from Morro Azul. In this context, the intervention of the State, in the name of public administration, in the community of Morro Azul is based on different premises, considers different criteria and is based on the legitimacy of another nature, which are very distant from the needs and of this community's reality, when hit by the "power over" of the State.

\section{Final Considerations}

For these reasons, the perception of public authority of Rio de Janeiro as a global city considers distinct referents of the Morro Azul community, which in its history has incorporated other elements and points of connection with international society, by the role of the Church, or by the direct investments of international companies, for example.

Morro Azul's relational axis is built with most consensual forms to integrate a globalized world through partnerships with government and the third sector. And its biographical axis is based on its good relationship with the catholic church as a reason for the good and healthy development of the community.

Mixing those two axes, Morro Azul distinct signs differs from to other communities, mainly with the discourse aiming to highlight the good relationship with the third sector, in a consensual way, having, for instance Priest Paulo as godfather. The catholic church is seen as a good partner for the community. This self-identity allows us to recognize the autonomy and protagonism of the community, as "power to".

The same impression of autonomy and partnership can be seen is the relationship of the community with other social actors, even the government. The complaints about government and other social actors are minimum considering the goals and trades they have together.

The collective identity of the Morro Azul community distances itself from other favelas. The distinctive signs are the following: i) resistance against favela's removal for urban politics. The community looked for partnerships with third sector and infrastructure construction, instead of fighting against public power; ii) the community didn't need to integrate public urban policies for favelas. Infrastructure, health and education services were provided by national and international partners; iii) proximity and consensus with the third sector, in the perspective of 
cooperation. The community did not submitted neither fight against State and Church.

Those distinct signs allow us to consider Morro Azul collective identity as different from other favelas. Its historical process is built much more on consensual relationships with protagonist and autonomy. It becomes them different from the ideal type of favela, which common sense is related to fights and opposite interests with other social actors, as "power over".

Specifically, in relation to identity, therefore, the hypothesis to be tested in the future is to affirm that the common sense of the favela as violent, submissive and dependent on the State, criminal organizations and the third sector must be relativized.

Recognizing the theoretical-methodological limits of this preliminary investigation regarding the taking of the community as a unity, universalizing it without considering the individualities of its constituent members, it is possible to affirm the collective identity of the community as "power to", constituted of social representations distinct from the "power over" as common sense applied to other favelas.

\section{REFERENCES}

[1] A. Mauricio. Evolução urbana do Rio de Janeiro. Ed. ZAHAR. IPLAN / J. Rio de Janeiro. 1987

[2] A. Edgar. L. Maria. Programa de promoção social, Caixa A (1/8), pasta Coleção Maria Luiza e Edgar Amarantes, Ed. Núcleo de Memória da PUC-Rio. Rio de Janeiro. 1959

[3] A. Hannah. On Violence. Ed. Harcourt, Brace \& World. New York. 1970

[4] Aristotle The Politics and The Constitution of Athens. Edited by Stephen Everson. Revised Student Edition. Cambridge University Press. Cambridge. 1996

[5] B. Jaime Larry. Reforma urbana e Revolta da Vacina na cidade do Rio de Janeiro. In: F. Jorge e D. Lucilia. (Org.) O Brasil Republicano - o tempo do liberalismo excludente: da Proclamação da Republica à Revolução de 1930. Civilização Brasileira. Rio de Janeiro. 2003

[6] B. Jaime Larry. Pereira Passos: um Haussman tropical. Secretaria Municipal de Cultura, Turismo e Esportes / Departamento Geral de Documentação e Informação Cultural, Divisão de Editoração. Rio de Janeiro. 1992

[7] B. Pierre. Language and Symbolic Power. Edited and introduced by John B. Thompson. Translated by Gino Raymond and Matthew Adamson. Polity Press. Oxford. 1991

[8] C. Lourdes. Quilombo, favela e periferia. A longa busca da cidadania. Fapesp. São Paulo. 2006

[9] D. Robert. Power as the Control of Behaviour. In Steven Lukes (ed) Power.
[10] New York University Press, 37-58. New York. 1986.

[11] D. Claude A crise das identidades. A interpretação de uma mutação. Ed. USP. São Paulo. 2009.

[12] D. Torben Bech. The Circular Structure of Power: Politics, Identity, Community. Ed. Verso. London. 1997.

[13] F. Michel. Two Lectures. In M. Kelly (ed) Critique and Power: 1 Recasting the Foucault/Habermas Debate. The MIT Press, 17-46. Cambridge. 1994

[14] G. Harold. Studies in Ethnomethodology. Prentice Hall. New Jersey. 1967

[15] G., Gerhard. Constitution and Use of Power. In: H. Goverde et al. (ed) Power in Contemporary Politics: Theories, Practices, Globalizations. Ed. Sage, 41-58. London. 2000

[16] G. Maria da Glória. Novas Teorias dos Movimentos Sociais. Loyola. São Paulo. 2010

[17] _. Teoria dos Movimentos Sociais. Paradigmas clássicos e contemporâneos Ed. Loyola. São Paulo: 1997

[18] S. Ubirajara Rodrigues. M. Helder. Plano de Desenvolvimento Local Morro Azul - PDLMA, Rio de Janeiro. 2016.

[19] H. Jürgen Hannah Arendt's Communications Concept of Power. In Steven Lukes (ed) Power. New York University Press, 75-93. New York. 1986

[20] H. Thomas Leviathan: or the Matter, Forme and Power of a Commonwealth Ecclesiasticall and Civil. Edition with an Introduction by Michael Oakeshott. Basil Blackwell. Oxford. 1957

[21] Machiavelli. The Prince. Edited by Quentin Skinner and Russell Price. Cambridge University Press. Cambridge. 1988

[22] M. Dominique. Nouvelles tendances en analyse du discours. Hachette. Paris: 1987

[23] P. Talcott. Sociological Theory and Modern Society. The Free Press. New York. 1967

[24] P. Sergio. F. Lílian. A reforma urbana e seu avesso: algumas considerações a propósito da modernização do Distrito Federal na virada do século. In: Revista Brasileira de História ${ }^{\circ}$ 8/9. Editora Marco Zero. Rio de Janeiro. 1985

[25] P. Michel (coord) Analyse du discours, langue et idéologies. $9 \mathrm{e}$ année. $\mathrm{n}^{\circ} 37$. Revue Langages. Paris1975. In: http://www.persee.fr/issue/lgge_0458-726x_1975 num 9 37

[26] P. Hanna Fenichel. Wittgenstein and justice: on the significance of Ludwig Wittgenstein for social and political thought.: University of California Press. Berkeley. 1972.

[27] R. Oswaldo Porto. A Era das Demolições: Cidade do Rio de Janeiro: 1870-1920. Secretaria Municipal de Cultura: Departamento Geral de Documentação e Informação Cultural. Rio de Janeiro. 1986

[28] F S. Carlos Nelson. Morro Azul in: Movimentos Urbanos no Rio de Janeiro. Zahar Editores Rio de Janeiro. 1981

[29] S. Milton. A urbanização brasileira, Edusp. São Paulo. 1993 
[30] S. Thatyana. A experiência da cruzada São Sebastião nas favelas da Praia do Pinto e do Morro Azul. Ed. PUC. Rio de Janeiro. 2016 in: http://www.puc-rio.br/pibic/relatorio_resu mo2016/relatorios_pdf/ccs/SER/SERThatyana\%20Siqueira. pdf

[31] V. Lílian Fessler. Modernidade e moradia: habitação coletiva no Rio de Janeiro, séculos XIX e XX. Ed. Sete Letras. Rio de Janeiro. 2002

[32] W. Max.Wirtschaft und Gesellschaft. 5te revidierte Auflage. Mohr. Tübingen. 1980
Websites Online Available:

[33] http://www.shooto.com.br/index.html

[34] http://bosqueecologiconossasenhoradelourdes.negocio.site

Oral Sources:

[35] Interviews with Ubirajara Rodrigues, 2017

[36] Interviews with João Calafate, Architect of City Hall - RJ, 2017 